\title{
Performance Indicators for Configuration Management
}

Tanja Minzenmay, Maximilian Zeiss, Masoud Niknam, and Jivka Ovtcharova

IMI, Karlsruhe Institute of Technology, Karlsruhe, Germany

\{tanjaminzenmay, zeiss.maximilian\} @gmail.com

\{masoud.niknam, jivka. ovtcharova\}@kit.edu

\begin{abstract}
Configuration Management (CM) with its aim to ensure functional and physical consistency between the product requirements and the reality during the whole lifecycle is becoming more and more important, since the awareness of the resulting advantages rises in many companies. The Institute for Information Management in Engineering at Karlsruhe Institute of Technology has developed a maturity model to evaluate the CM maturity for different organizations on the basis of different CM dimensions. The following paper enhances the capability of this model by developing performance indicators, which are aimed at measuring the quality of implemented CM activities as a supplement to their extent of application, which was measured before. Such indicators have been developed based on an extensive state-of-the-art analysis and were validated and refurbished through interviews with industrial experts.
\end{abstract}

Keywords: Configuration Management, Product Lifecycle Management, Performance Measurement, Maturity Model.

\section{Introduction}

Configuration Management (CM) can be seen as a coordinated framework of activities to manage and control configurations $[1,2]$. Due to the primary aim of keeping consistency between what needs to be there, what is actually there and what we say is there [3], CM provides several benefits. Many researchers confirm that CM exerts positive effects on product quality, product lifecycle costs and therefore on the ability to compete in an environment with growing complexity $[3,4,5]$. Niknam \& Ovtcharova [6] have developed a $\mathrm{CM}$ maturity assessment framework which enables the organizations to investigate their CM maturity with respect to the extent of CM application throughout the organization. However, for a higher framework capability, concrete measurements are needed to assess the CM quality. Many organizations are already measuring their overall performance by using performance indicators (PIs), which usually control important business units or the organization as a whole[7]. Well known examples are the Return on Investment (ROI) or the amount spent on research and development. In order to ascertain organizations performance and success in high levels, the performance of every discipline shall be investigated by utilization of detailed PIs. Thus, the aim of this paper is to develop and present PIs for Configuration 
Management based on the critical success factors and dimensions in the CM Maturity Model [6].

The remainder of this paper is structured as follows. In section 2, the CM Maturity Model of [6] is briefly presented. Later, a general introduction to performance indicators is given. The research methodology is described in section 4 and in section 5 the PIs developed by the authors are introduced. Finally, section 6 gives a conclusion and outlook of future work.

\section{Configuration Management Maturity Model}

Since maturity models available do not cover CM in detail, Niknam \& Ovtcharova [6] have developed the Configuration Management Maturity Model $\left(\mathrm{CM}^{3}\right)$. They define five primary dimensions of CM, which influence the level of success for an organization's application of CM discipline. These five dimensions are Strategy \& Performance, Processes, Information Technology, Organization \& Value-stream as well as Knowledge \& Support. Furthermore, they have created sub-dimensions or critical success factors, describing particular activities and attributes of the each primary dimension which needs to be considered for implementation and establishment of an effective CM discipline. (Figure 1)

\begin{tabular}{|c|c|c|c|c|}
\hline $\begin{array}{l}\text { Strategy \& } \\
\text { Performance }\end{array}$ & Processes & $\begin{array}{l}\text { Information } \\
\text { Technology }\end{array}$ & $\begin{array}{l}\text { Organization } 8 \\
\text { Value-Stream }\end{array}$ & $\begin{array}{l}\text { Knowledge\& } \\
\text { Support }\end{array}$ \\
\hline $\begin{array}{l}\text { CM Strategic } \\
\text { Objective and Policy }\end{array}$ & Clear processes & $\begin{array}{l}\text { High level of } \\
\text { visualization and } \\
\text { user-friendliness }\end{array}$ & $\begin{array}{l}\text { Suitable CM Organization } \\
\text { Structure with Respect to } \\
\text { Organization Complexity } \\
\text { and CM Needs }\end{array}$ & $\begin{array}{l}\text { Standard CM } \\
\text { Terminology and } \\
\text { Knowledge Support } \\
\text { Accessible by } \\
\text { Stakeholders }\end{array}$ \\
\hline $\begin{array}{l}\text { Deployment of CM } \\
\text { Strategy in Different } \\
\text { Organization Levels }\end{array}$ & Standard processes & $\begin{array}{l}\text { Integration of CM- } \\
\text { Tool with other IT- } \\
\text { Systems }\end{array}$ & $\begin{array}{l}\text { Defined Roles and } \\
\text { Responsibilities for CM } \\
\text { Personnel }\end{array}$ & $\begin{array}{l}\text { Regular CM-Related } \\
\text { Training Activities }\end{array}$ \\
\hline $\begin{array}{l}\text { Communication of the } \\
\text { Deployed Strategy to } \\
\text { Stakeholders }\end{array}$ & $\begin{array}{l}\text { Process awnership, } \\
\text { maintenance and } \\
\text { update based on } \\
\text { feedbacks }\end{array}$ & $\begin{array}{l}\text { Supporting the CM- } \\
\text { Functionalities }\end{array}$ & $\begin{array}{l}\text { Cross-Functional } \\
\text { Collaboration among } \\
\text { Different Stakeholders for } \\
\text { CM Purposes }\end{array}$ & $\begin{array}{l}\text { Accessibility and } \\
\text { Promotion of Latest } \\
\text { Standards, Lessons } \\
\text { Learned, Best Practices } \\
\text { and Benchmarks }\end{array}$ \\
\hline $\begin{array}{l}\text { KPIs for Performance } \\
\text { Measurement }\end{array}$ & $\begin{array}{l}\text { Stakeholder access } \\
\text { to processes }\end{array}$ & $\begin{array}{l}\text { Solid IT-Tools all } \\
\text { over the } \\
\text { Organization for all } \\
\text { Lifecycle Phases }\end{array}$ & $\begin{array}{l}\text { Consideration of } \\
\text { Suppliers and } \\
\text { Subcontractors in CM } \\
\text { Activities }\end{array}$ & $\begin{array}{l}\text { Support and } \\
\text { Empowerment of CM } \\
\text { Discipline by Top } \\
\text { Management }\end{array}$ \\
\hline $\begin{array}{l}\text { Regular } \\
\text { Measurement and } \\
\text { Update of KPls }\end{array}$ & $\begin{array}{l}\text { Process } \\
\text { customizability for } \\
\text { different scenarios }\end{array}$ & $\begin{array}{l}\text { Authorization } \\
\text { Capabilities for } \\
\text { different CM } \\
\text { activities }\end{array}$ & $\begin{array}{l}\text { Involvement of Key } \\
\text { Stakeholders in Major } \\
\text { Configuration Changes }\end{array}$ & $\begin{array}{l}\text { Communication of } \mathrm{CM} \\
\text { Benefits to Stakeholders } \\
\text { by Top Management }\end{array}$ \\
\hline
\end{tabular}

Fig. 1. CM Maturity Model sub-dimensions

For assessing the current CM maturity of various industries and validating the developed critical success factors, Niknam \& Ovtcharova [8] have done a cross-industry survey using the $\mathrm{CM}^{3}$ model. The results illustrate a high potential for improvement in $\mathrm{CM}$ with respect to its penetration level in the organization. 


\section{Measurement by Performance Indicators}

In this paper, as outlined in the Introduction, the assessment framework of $\mathrm{CM}^{3}$ is enhanced by the development of performance indicators. These performance indicators shall measure the application quality of each sub-dimension. Therefore, only the quality of CM-activities concerning the given sub-dimensions is the point of interest, and not "well-known" measures which focus on the overall performance of a company or different organizational units, as for example Return On Investment. Quality in the context of the indicators refers to the question: "How 'good' is activity A performed?".

Performance measurement in general is used for monitoring and improving performance. Klingebiel [7] highlights that no matter how the performance measurement system looks like, three main perceptions are important:

1. You cannot manage what you cannot measure

2. What gets measured gets done

3. Measurement influences behavior

The three perceptions can be transferred to the context of this paper, since the aim is to manage the improvement of CM.

\section{$4 \quad$ Research Methodology}

In order to get a first list of possible PIs for the different sub-dimensions, a broad literature analysis was done. Based on this first collection, the authors conducted semi-structured interviews with industry experts to both validate the indicators and adjust them with respect to their feasibility of application, data availability and importance. The interviews have been done with four experts, coming from automotive and aerospace industry, from plant engineering industry as well as engineering consulting. Summarized about 7 hours of interview time have been done. As a result of the interviews some of the indicators have been approved without any further remarks, some have been supplemented for a better understanding, and a few have been excluded because of doubts about the general significance.

\section{$5 \quad$ Performance Indicators}

The authors propose the following performance indicators. They are presented in the following format in 3 columns.

\begin{tabular}{|l|l|l|}
\hline Performance Indicators: & Initial source: & Expert Comments: \\
$\%$ - percentage & [ ] : Reference & V : validated \\
$\#$ - number/amount of & A : Authors' proposal & U : updated \\
$\varnothing$ - average & I : Interview & E : emerged \\
& & $-:$ Not sure \\
\hline
\end{tabular}




\section{Strategy \& Performance}

CM Strategic Objective and Policy: For successful CM, objectives and policy should be available and be adapted to the corporate strategy

- \% to which CM strategic objectives are derived from overall strategy:
the CM strategy needs to fit to the company's overall goals to support
their achievement
- Actual frequency / target frequency of updating CM objectives: CM
objectives need to be rechecked regularly to be adapted to new corpo-
rate goals
- \% to which CM policy \& objectives are covering all main CM activi-
ties in the organization: proper policy and objectives should cover all
important subjects to avoid confusion and constitute a guideline

\begin{tabular}{|l|l|}
\hline 9$][10]$ & $\mathrm{V}$ \\
{$[9][11]$} & $\mathrm{U}$ \\
{$[12][13]$} & $\mathrm{V}$ \\
\hline
\end{tabular}

Deployment of CM Strategy in Different Organization Levels: CM strategy needs to be deployed to all levels to provide adapted objectives for all teams

\begin{tabular}{|c|c|c|}
\hline $\begin{array}{l}\text { - \% of deployed goals, which can be clearly linked to a higher CM ob- } \\
\text { jective }\end{array}$ & $\begin{array}{l}{[10][14]} \\
{[15]}\end{array}$ & V \\
\hline $\begin{array}{l}\text { - \# CM units having a mission statement that clearly defines their objec- } \\
\text { tives and mission: it is important that all organizational units know } \\
\text { what they need to do to achieve main CM objectives }\end{array}$ & [I] & E \\
\hline
\end{tabular}

Communication of the Deployed Strategy to Stakeholders: To be able to support CM objectives and policy guidelines, the strategy has to be communicated to the stakeholders

- \# of strategic deviations associated to communication: communication quality can be assessed by conducting audits.

- \% employees who can explain the CM strategy and what it means in terms of their daily work: if employees know how their work contributes to $\mathrm{CM}$ success the communication has worked properly

- Effectiveness of policy implementation: the policy should not only be mentioned on a document but it should be understood and applied in the operative business

\begin{tabular}{|l|l}
{$[16]$} & $\mathrm{U}$ \\
{$[16]$} & $\mathrm{V}$ \\
{$[14][15]$} & $\mathrm{V}$ \\
\hline
\end{tabular}

KPIs for Performance Measurement: The fulfillment of objectives needs to be measured with Key Performance Indicators

- Quality of data available for KPI results (sufficient quantity, completeness): if the database for the KPI application is not sufficient, then the KPI results won't be reliable

- \# of KPIs: an organization should always focus on a limited number of KPIs to keep the focus

- \% KPIs linked to strategic objectives and critical success factors:

- \% KPIs from which an action plan can directly be started in case outcoming results are bad: KPIs should always point out success and drawbacks

- Frequency of KPI reviewing and improvement: the usefulness of a KPIs should be checked regularly

\begin{tabular}{|l|l|}
\hline 17$][18]$ & $\mathrm{V}$ \\
{$[19]$} & \\
{$[18]$} & - \\
{$[20]$} & $\mathrm{V}$ \\
{$[18]$} & - \\
{$[18]$} & $\mathrm{U}$
\end{tabular}


Regular Measurement of KPIs: KPIs needs to be measured regularly

- Frequency of measurement and reporting: depending on the focus the measurement needs to take place constantly and results be reported

\section{Processes}

Clear processes for different org. units, projects and lifecycle phases: Processes should be defined, transparent, controllable, effective, efficient, straightforward, robust and at a right level of detail.

- \# questions/requests about processes due to a lack of understanding: clear processes should be defined in a comprehensible way

- \% cases where the result of the process is constructive in a way that predefined objectives are achieved

[18] [17] $\mathrm{V}$

Standard processes: Standard CM processes like configuration identification, baselining, product structure management, change evaluation -control \& implementation, status accounting and configuration audits.

- $\emptyset$ time to approve Engineering Changes

- $\emptyset$ costs per change

- \# non-confirmative configurations at the final product: all standard processes are trying to prevent these deviations

- Frequency of reports and audits

- \# deviations to make a "fast" design change: this kind of deviation should be totally avoided

$[21]$

$[21,22]$

Process ownership, maintenance and update based on feedbacks: A specific person is responsible for a process - processes are maintained, updated and improved - feedback among the employees is encouraged and maybe rewarded.

- $\emptyset$ benefit per feedback: if possible to measure financial

- Frequency of feedbacks: more reasonable if combined with the benefit

- \% of processes with a specific and active process owner, who is responsible for process audit and the interfaces with adjacent processes

\begin{tabular}{l|c}
{$[17,23,24]$} & $\mathrm{V}$ \\
{$[17,23,24]$} & $\mathrm{V}$ \\
{$[\mathrm{I}]$} & $\mathrm{E}$ \\
{$[23]$} & $\mathrm{V}$ \\
{$[17]$} & -
\end{tabular}

Stakeholder access to processes: Access of stakeholders to process information must be defined and managed in an efficient way.

- $\varnothing$ Time until process information can be found by the stakeholder

- \% of satisfied stakeholders regarding accessing process information

\begin{tabular}{l|c}
\hline$[A]$ & $\mathrm{V}$ \\
{$[21,22]$} & $\mathrm{U}$ \\
{$[21]$} & $\mathrm{U}$
\end{tabular}

Process customizability for various scenarios: Processes should be able to handle different requirements in a continuously changing working environment.

- Availability of shortcuts: increases the efficiency for less complex scenarios (also called fast tracks)

- \# scenarios which cannot be covered by the company's processes: this can be minimized by very robust or flexible processes - some industrial sectors need very flexible processes others very robust ones

\begin{tabular}{l|l}
{$[\mathrm{A}]$} & $\mathrm{V}$ \\
{$[25,26]$} & $\mathrm{U}$
\end{tabular}




\section{Information Technology}

High level of visualization and user-friendliness: IT-tools should be easy to handle and operate as well as being capable of providing all the information needed. The user should like the usage of these tools and recognize the benefits easily.

- $\emptyset$ time a user needs to complete a specific task: this standard tasks must be executed with the IT-system

- IT-happiness-score: measuring the satisfaction level of stakeholders with the CM IT system

- Meaningful and intuitive wording is used for the user interface and wrong data typed in by the user is avoided

\begin{tabular}{|c|c|}
\hline [27] & \\
\hline [27] & \\
\hline $\begin{array}{l}{\left[\begin{array}{ll}28, & 29, \\
30,26]\end{array}\right.}\end{array}$ & \\
\hline
\end{tabular}

\section{Integration of CM-Tool with other IT-Systems}

- \% time spent on finding CM-information in the IT system out of overall time spent on CM-activities: if many IT-systems must be accessed, systems are not integrated efficiently

\section{Supporting the CM-Functionalities}

- \# processes developed based on given IT-systems: should be minimized because the IT-systems must be specified by CM needs and processes and not the other way around

- \% CM-activities supported by IT

[A]

\begin{tabular}{|l|l|}
{$[\mathrm{A}]$} & $\mathrm{V}$ \\
{$[23,24]$} & $\mathrm{V}$
\end{tabular}

\section{Solid IT-Tools all over the Organization for all Lifecycle Phases}

- \# cases during the product lifecycle where the format of information needs to be changed because of different IT-tools or databases

- Frequency of data backups

[23]

$[32]$

V

\section{Authorization Capabilities for different CM activities}

\begin{tabular}{l|l|l|}
\hline $\begin{array}{l}\text { - \# access rights following logical, transparent and comprehensible rules } \\
\text { which are defined by the company }\end{array}$ & {$[33,34]$} & $\mathrm{V}$ \\
- $\emptyset$ loss due to wrong authorization & {$[\mathrm{A}]$} & - \\
\hline
\end{tabular}

\section{Organization \& Value Stream}

Suitable CM Organization Structure with Respect to Organization Complexity and CM Needs

- \# of CM employees / product complexity: if there are different product programs with different variants and the amount of products are high, more contributions are necessary

- CM integration / organization complexity: for managing high complexity a high degree of integration, defined as communication, control and coordination, is necessary

[9] [35] U 
Defined Roles and Responsibilities for CM Personnel: all required roles need to be defined clearly and the responsibility needs to be distributed to individuals

\begin{tabular}{|l|l|l|}
\hline $\begin{array}{l}\text { \# escalations caused by unclear responsibilities (difficult to measure, } \\
\text { could be also assess in audits): if responsibilities are unclear misun- } \\
\text { derstandings will occur which can end in escalations }\end{array}$ & V \\
- \% roles which are clearly defined and documented & [A] & E \\
\hline
\end{tabular}

Cross-Functional Collaboration among Different Stakeholders for CM Purposes: CM is a cross-functional discipline, which is why the collaboration between functions is required by CM's very nature

- \% of process target achievement for each value chain element: an effective cross-functional collaboration between stakeholders along the value chain will enable every chain element to achieve its goals corresponding to $\mathrm{CM}$ activities

- Cycle time per changes involving the value-chain: if collaboration works well, such changes should be able to get passed through fast

- \# revisions for change changes involving the value-chain: if collaboration works well revisions should not be necessary

\begin{tabular}{|l|l}
\hline AA] & E \\
{$[\mathrm{A}]$} & $\mathrm{E}$ \\
{$[\mathrm{A}]$} & $\mathrm{E}$ \\
\hline
\end{tabular}

Consideration of Suppliers and Subcontractors in CM Activities: suppliers need to be integrated in CM activities to ensure the CM targets for sourced parts

\begin{tabular}{|c|c|c|}
\hline $\begin{array}{l}\text { - \# non-conformities resulted from lack of value-chain involvement: if } \\
\text { the exchange of information about changed specifications, require- } \\
\text { ments etc. does not work well, non-conformities can occur } \\
\text { - \# of non-conformities (opposite perspective): if the contractor does not } \\
\text { deliver what has been specified, non-conformities can occur }\end{array}$ & [13] [5] & $\mathrm{U}$ \\
\hline \multicolumn{3}{|l|}{ Involvement of Key Stakeholders in Major Configuration Changes: } \\
\hline $\begin{array}{l}\text { - \# of complains after changes were implemented (internal or external) } \\
\text { - \# of review cycles needed for changed implementation: if all } \\
\text { stakeholders are involved from the beginning, changes can be de- } \\
\text { fined in detail and implemented without any more changes to the } \\
\text { change }\end{array}$ & $\begin{array}{l}\text { [5] [13] } \\
{[\mathrm{A}]}\end{array}$ & $\begin{array}{l}\text { V } \\
\text { E }\end{array}$ \\
\hline
\end{tabular}

\section{Knowledge and Support}

\section{Standard CM Terminology and Knowledge Support Accessible by Stakeholders}

- Frequency of updating the provided information: ensuring actuality of information

- $\emptyset$ time to find the needed information: ensures a convenient access to knowledge

- \# of audit findings illustrating insufficient knowledge of the employees in $\mathrm{CM}$

\begin{tabular}{|l|l|}
\hline$[19][36]$ & $\mathrm{V}$ \\
\hline$[36][19]$ & $\mathrm{V}$ \\
\hline [A] & $\mathrm{E}$ \\
\hline
\end{tabular}


Regular CM-Related Training Activities: Employees need to be prepared for CM tasks by trainings to ensure the quality of the task execution

- \% of CM activities for which training is available

- $\emptyset$ amount of training taken by each employee associated with CM

- \# of obligated trainings for each role: if the training is necessary to fulfill a role/ tasks it is a sign for a high quality of the training

\begin{tabular}{l|l}
{$[17][24]$} & $\mathrm{V}$ \\
{$[24][17]$} & $\mathrm{V}$ \\
{$[\mathrm{A}]$} & $\mathrm{E}$
\end{tabular}

Accessibility and Promotion of Latest Standards, Lessons Learned, Best Practices and Benchmarks
- \% of projects for which CM lessons learned is recorded and ac- cessible by future stakeholders
- \% coverage of CM activities by standards and benchmark documents accessible to corporate search engines:
- \% of lessons learned used in future projects

\begin{tabular}{l|l}
{$[19]$} & $\mathrm{V}$ \\
{$[19]$} & $\mathrm{V}$ \\
{$[9]$} & $\mathrm{U}$
\end{tabular}

Support and Empowerment of CM Discipline by Top Management: To ensure the fulfillment and acceptance of CM, management support is necessary

\begin{tabular}{l|l|l} 
- \% of management attending CM meetings: & {$[\mathrm{A}]$} & E \\
$\begin{array}{l}\text { - Frequency of management demands for CM reports: indicates that } \\
\text { management's attention to CM }\end{array}$ & E
\end{tabular}

Communication of CM Benefits to Stakeholders by Top Management: For motivation and acceptance of CM it is necessary that the benefits are communicated to all stakeholders

- Frequency of promoting $\mathrm{CM}$ as an influential discipline by Top Management

\section{Outlook}

In this paper, performance indicators for the sub-dimensions of the Configuration Management Maturity Model have been introduced. The developed PIs extend the model's functionality and enable the assessment of not only the implementation extent of $\mathrm{CM}$ in the target organization, but also the quality of this implementation. The PIs so far are identified on the basis of literature review and expert interviews. A necessary further step is to apply the PIs in a case organization to find out the feasibility measuring them. The trade-off between the importance and measurement feasibility shall be identified and a more applicable list of KPIs shall be developed. Moreover, to enable an assessment and identifying various maturity levels, an extensive cross-industry assessment is required to understand various available ranges for each PI. After defining the levels the next step would be to define activities which support organizations in achieving the next maturity level. 


\section{References}

[1] BS ISO 10007. Quality management systems: Guidelines for configuration management, British standards (2003)

[2] (IAQG), International Aerospace Quality Group, Supply chain management handbook, chapter 11 (2012), http: / /www. sae.org/iaqg/publications/ (accessed December 2013)

[3] International Atomic Energy Agency (IAEA) Report Series, Application Of Configuration Managemen. In: Nuclear Power Plants (2010)

[4] Rouse, W., Sage, A.: Handbook of Systems Engineering and Management, pp. 267-289. Jon Wiley \& Sons (2011)

[5] Dvir, D., Lipovetsky, S., Shenhar, A., Tishler, A.: In search of project classification: a non-universal approach to project success factors. Research Policy 27 (1998)

[6] Niknam, M., Bonnal, P., Ovtcharova, J.: Configuration Management Maturity in Scientific Facilities. International Journal of Advanced Robotics, Special issue on Robotics and Systems Engineering in Scientific Facilities (2013)

[7] Klingebiel, N.: Performance measurement-systeme. Das Wirtschaftsstudium 26(7) (1997)

[8] Niknam, M., Ovtcharova, J.: Towards Higher Configuration Management Maturity. In: Bernard, A., Rivest, L., Dutta, D. (eds.) PLM 2013. IFIP AICT, vol. 409, pp. 396-405. Springer, Heidelberg (2013)

[9] Hass, A.M.J.: Configuration Management principles and practice. Addison-Wesley, Boston (2003)

[10] Robbins, S., De Cenzo, D., Coulter, M.: Fundamentals of management. Pearson, Boston (2013)

[11] Rohm, H.: Is There Any Strateg. In: your Strategic Plan, Balanced Scrorecard Institute, Strategy Management Group (pub.), Cary, North Carolina (2008), http: / /balancedscorecard.org/Portals / 0 / PDF / IsThereAnyStrateg yInYourStrategicPlanWeb.pdf (assessed on January 11, 2014)

[12] Ulrich, H.: Unternehmungspolitik. Gesammelte Schriften Band 2, 11 (2001)

[13] Department of Defense, MIL-HDBK-61-A(SE) (2001)

[14] CMS Policy for Configuration Management, (2012) Centers for Medicare and Mediacaid Services, https://www.cms.gov/Research-Statistics-Data-andSytems/CMS-Information-

Technolgy/SystemLifecycleFramework/downloads/cmpolicy.pdf (accessed on March 04, 2014)

[15] Martin, J.: Information Engineering. A triology, Book II, pp. 70-95. Prentice Hall, Englewood Cliffs (1990)

[16] Barret, D.: Change Communication: using strategic employee communication to facilitate major changes. Corporate Communications: an International Journal, 219-231 (2002)

[17] Watts, F.B.: Configuration Management Metrics. Elsevier Inc. (2009)

[18] Eckerson, W.: Performance Dashboards: Measuring, monitoring and managing your business, pp. 197-212. John Wiley, Hoboken (2006)

[19] Maier, R.: Knowledge Management Systems. In: Information and Communication Technologies for Knowledge Management, vol. 248, pp. 110-111. Springer, Berlin (2004)

[20] Parmenter, D.: Key Performance Indicators: Developing, Implementing and Using Winning KPIs, 2nd edn., pp. 1-10. John Wiley, Hoboken (2007)

[21] Fischermanns, G.: Praxishandbuch Prozessmanagement. Verlag Dr. Götz Schmidt, Gießen (2009) 
[22] Becker, T.: Prozesse in Produktion und Supply Chain optimieren. Springer (2008)

[23] Lyon, D.D.: Practical CM, Best Configuration Management Practices. ButterworthHeinemann (1999)

[24] Watts, F.B.: Engineering Documentation Control Handbook. William Andrew Inc. (2008)

[25] Bourne, L.: Stakeholder Relationship Management. Gower Publishing (2009)

[26] ISO 9241-12, Presentation of information (2011)

[27] Nielson, J.: Usability Engineering. Academic Press, San Diego (1993)

[28] Heinecke, A.M.: Mensch-Computer-Interaktion. Springer (2012)

[29] Plaisant, B.S.A.C.: Designing the User Interface. Pearson Education Inc. (2010)

[30] Schneiderman, B.: The eyes have it: A task by data type taxonomy for information visualizations, Institute for Systems Research University of Maryland (1996)

[31] Vaupel, J., Birkhölzer, T.: IT-Architekturen. VDE Verlag (2003)

[32] Patton, P.C., Jayaswal, B.K.: Design for Trustworthy Software. Pearson Education Inc. (2007)

[33] Benantar, M.: Access Control Systems. Springer (2006)

[34] Lampson, B.W.: Protection. In: Proceedings of the 5th Princeton Conference on Information Sciences and Systems (1971)

[35] Baccarini, D.: The concept of project complexity - a review. International Journal of Project Management, 201-204 (1996)

[36] Lehner, F.: Wissensmanagement: Grundlagen, Methoden und technische Unterstützung, 3rd edn. Hanser, Wien (2009)

[37] Doppler, K.: Unternehmenswandel gegen Widerstände, Change Management mit den Menschen. Campus Verlag, Frankfurt am Main (2011) 